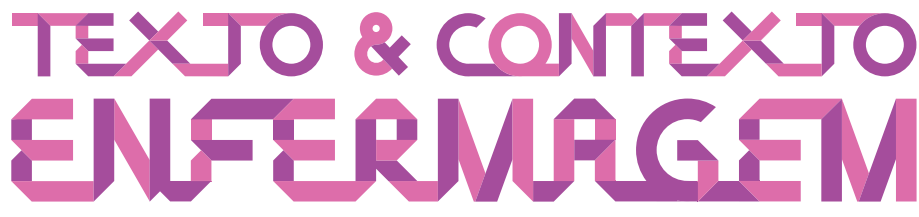

TEXT \& CONTEXT NURSING TEXTO \& CONTEXTO ENFERMERÍA

\title{
TEACHING OF THERAPEUTIC PLAY \\ AT THE UNDERGRADUATE LEVEL IN \\ NURSING: DIDACTIC ACTIONS AND \\ STRATEGIES USED BY PROFESSORS
}

\author{
Edmara Bazoni Soares Maia' ${ }^{1}$ (D) \\ Conceição Vieira da Silva Ohara' ${ }^{1}$ (i) \\ Circéa Amália Ribeiro' ${ }^{1}$ (D)
}

1Universidade Federal de São Paulo, Escola Paulista de Enfermagem, São Paulo, Brasil

\begin{abstract}
Objective: to present and discuss actions and strategies used by professors who teach therapeutic play in the Undergraduate Courses in Nursing.

Method: qualitative research, that used symbolic interactionism as its theoretical framework, and Grounded Theory as its methodological framework. The scenario was the courses involving the theoretical-practical teaching of pediatric nursing, included in the curriculums of the Undergraduate Courses in Nursing. A total of 18 lecturers and three nurses participated, all involved in the process of teaching therapeutic play in the theoretical-practical scenario. Data were collected through participant observation and semistructured interviews.
\end{abstract}

Results: it was revealed that the mobilization of the professors to teach therapeutic play in the Undergraduate Courses is permeated by a constant concern with offering and promoting significant learning to the student. They seek to do this through teaching strategies that involve: dramatization of therapeutic play sessions, the recovery of infancy and of playing, the use of audiovisual resources that raise awareness of learning, realistic simulation as innovation, the extending of possibilities of using Therapeutic Play, the re-presenting of therapeutic play to the student at the start of the practical activity, the providing of material for this practice, and the inclusion of the issue in the assessment process.

Conclusion: the results contribute to assisting the lecturers in the task of awakening and introducing the student to the universe of therapeutic play, promoting her learning and systematic incorporation 
into academic life and, in the future, as a nurse, when she shall promote the inclusion of therapeutic play in the care provided to the child - in order to preserve and protect the child's right to receive qualified care.

DESCRIPTORS: Teaching. Nursing education. Pediatric nursing. Play and playthings. Problembased learning.

\section{ENSINO DO BRINQUEDO TERAPÊUTICO NA GRADUAÇÃO EM ENFERMAGEM: AÇÕES E ESTRATÉGIAS DIDÁTICAS UTILIZADAS POR PROFESSORES}

\section{RESUMO}

Objetivo: apresentar e discutir ações e estratégias utilizadas por professores que ensinam o brinquedo terapêutico nos Cursos de Graduação em Enfermagem.

Método: pesquisa qualitativa, que utilizou o Interacionismo Simbólico como referencial teórico e metodológico a Teoria Fundamentada nos Dados. O cenário constituiu-se de disciplinas que envolvem o ensino teórico-prático da enfermagem pediátrica, inseridas nos currículos do Curso de Graduação em Enfermagem. Participaram 18 docentes e três enfermeiros, envolvidos com o processo de ensino do brinquedo terapêutico no cenário teórico-prático, sendo os dados coletados por meio de observação participante e entrevista semiestruturada.

Resultados: revelou-se que a mobilização do professor para ensinar o brinquedo terapêutico no Curso de Graduação é permeada por constante preocupação em oferecer e promover ao aluno uma aprendizagem significativa, o que busca fazer por meio de estratégias de ensino que envolvem: dramatização de sessões do brinquedo terapêutico, resgate da infância e do brincar, utilização de recursos audiovisuais sensibilizadores da aprendizagem, a simulação realística como inovação, a ampliação de possibilidades do uso do brinquedo terapêutico, o reapresentar do brinquedo terapêutico ao aluno no início da atividade prática, providenciar o material para essa prática e a inserção da temática no processo de avaliação.

Conclusão: os resultados contribuem para auxiliar os docentes na tarefa de despertar e introduzir o aluno no universo do brinquedo terapêutico, favorecendo seu aprendizado e a incorporação sistemática na vida acadêmica e, futuramente, como enfermeiro, quando deverá promover a inserção do brinquedo terapêutico na assistência à criança, para preservar e proteger o seu direito de receber um atendimento qualificado.

DESCRITORES: Ensino. Educação em enfermagem. Enfermagem pediátrica. Jogos e brinquedos. Aprendizagem baseada em problemas.

\section{ENSEÑA DEL JUEGO TERAPÉUTICO EN LA GRADUACIÓN EN ENFERMADO: ACCIONES Y ESTRATEGIAS DIDÁCTICAS UTILIZADAS POR PROFESORES}

\section{RESUMEN}

Objetivo: presentar y discutir acciones y estrategias utilizadas por profesores que enseñan el juego terapéutico en los Cursos de Graduación en Enfermería.

Método: investigación cualitativa, que utilizó el Interacionismo Simbólico como referencial teórico y metodológico la Teoría Fundamentada en los Datos. El escenario se constituyó de disciplinas que 
involucran la enseñanza teórico-práctica de la enfermería pediátrica, insertadas en los currículos del Curso de Graduación en Enfermería. Participaron 18 docentes y tres enfermeros, involucrados con el proceso de enseñanza del juguete terapéutico en el escenario teórico-práctico, siendo los datos recolectados por medio de observación participante y entrevista semiestructurada.

Resultados: se reveló que la movilización del profesor para enseñar el juego terapéutico en el Curso de Graduación está impregnada por constante preocupación en ofrecer y promover al alumno un aprendizaje significativo, lo que busca hacer por medio de estrategias de enseñanza que involucran: dramatización de sesiones el uso de recursos audiovisuales sensibilizadores del aprendizaje, la simulación realista como innovación, la ampliación de posibilidades del uso del juego terapéutico, el reapresión del juego terapéutico al alumno al inicio de la actividad práctica, providenciar el juguete terapéutico, rescate de la infancia y del juego, utilización de recursos audiovisuales sensibilizadores del aprendizaje, la simulación realista como innovación, la ampliación de posibilidades del uso del juego terapéutico, material para esa práctica y la inserción de la temática en el proceso de evaluación.

Conclusión: los resultados contribuyen a auxiliar a los docentes en la tarea de despertar e introducir al alumno en el universo del juego terapéutico, favoreciendo su aprendizaje y la incorporación sistemática en la vida académica y, en el futuro, como enfermero, cuando deberá promover la inserción del juguete terapéutico en la asistencia al niño, para preservar y proteger su derecho a recibir una atención cualificada.

DESCRIPTORES: Enseñanza. Educación en enfermería. Enfermería pediátrica. Juego e implementos de juego. Aprendizaje basado en problemas.

\section{INTRODUCTION}

In recent years, the area of education in Nursing has advanced and significant changes have occurred since the incorporation of the National Curricular Guidelines (DCNs) in the Undergraduate Courses in Nursing. The structural axes of the process of professional training should be fundamentally based in the adoption of a theoretical-pedagogical framework that supports significant learning that is transformative and suited to the social and professional needs presented at the current time. ${ }^{1}$

The DCNs guide the curricular organization for the training of nurses who are generalist, humane, critical and reflexive, with the knowledge necessary for exercising general competencies and skills, such as attention to health, decision-making, leadership, administration, management, ongoing education and communication. ${ }^{2}$

In this regard, the courses directed towards care for the child must also form part of the curriculums of the Undergraduate Courses in Nursing, with theoretical and practical content developed over the course of the training - and must be obligatorily included in the supervised curricular placement, in an integrated and interdisciplinary way. ${ }^{3}$

As a result, the teaching must be conducted based in respect for the child's rights and legal representatives, in the exercising of autonomy, freedom to take decisions, appropriate information understood by all, and with the gradual participation of the child, respecting her cognitive development and capacity for understanding. ${ }^{4}$

Furthermore, it must defend the comprehensiveness of the care for the newborn, child, adolescent and family, promoting the teaching of effective communication strategies with all these actors, as an expression of the humanized care, and must enable the students to develop concepts including the valuing of playing as a basic need of the child, and the promotion of this in all the scenarios of care. ${ }^{5}$ 
In this regard, the child's right to play must be protected, preserved and promoted by all professionals involved in her care. ${ }^{6}$

In attending these principles, we emphasise the teaching of therapeutic play (TP), the technology of care that facilitates communication between the nurse, child and family, with the potential to favor the bond and the promotion of the emotional well-being of all those involved. ${ }^{7}$

TP was developed by nurses, and since the 1990s has been classified into three types: dramatic or cathartic, a modality in which the child can express herself through play and dramatize new, difficult-to-articulate experiences - and, through this, become emotionally secure; instructional, that allows the professional to explain procedures and/or other events which are unknown to the child; and physiologically enhancing, when the child participates in activities in order to improve her physical status through play. ${ }^{8}$

All this potential for humanized care, promoting the child's rights, evidences the need and importance for TP to be taught in the Undergraduate Courses in Nursing.

Although studies have evidenced that the majority of nurses come to know of this during their undergraduate studies, many continue to feel unable to apply it, or leave it to one side when providing care to children - prioritizing the managerial demands of the unit, associated with the predominance of the understanding that this action is superfluous in comparison with others. They indicate lack of knowledge and training, and failure to understand or be aware of TP as an advanced nursing practice, as hindrances to its application in clinical practice. ${ }^{9-11}$

Such evidence led to certain questions: if the nurse interacts with the content of TP during her Undergraduate Course, and does not feel secure in applying it, what happened during her training? How is the teaching taking place? Are the teaching methodologies used appropriate, and capable of involving the student and promoting her learning?

A review of the literature on this topic in national and international databases indicated a scarcity of studies focusing on the teaching of TP in Undergraduate Courses in Nursing, evidencing a vast field of investigation to be explored.

Reflecting on the role of the professors who teach TP on Undergraduate Courses in Nursing throws light on their responsibility to transmit values and ethical principles to the students, involving respect for the child's personal integrity and autonomy - including to take decisions ${ }^{7,12}$ which, in situations involving young ages, can be encouraged and valued through dialogue based on TP sessions, giving the child the opportunity to act through play, exercising her role in decision-making and recovering her autonomy and self-control as she plays. ${ }^{12-13}$

Hence, this article aims to present and discuss actions and strategies used by professors who teach TP in the Undergraduate Courses in Nursing. It forms part of a study which sought to investigate the experience of the professor in the process of teaching TP in the academic scenario, and to construct a theoretical model that is representative of this experience. ${ }^{14}$

\section{METHOD}

A qualitative study that used Symbolic Interactionism as its theoretical framework, intending to analyze the human experiences, focusing on the nature of the interaction - that is, the activities of social dynamics that take place between people, emphasizing the meanings that they attribute to the events as determinants of the actions that they perform. ${ }^{15}$

The methodological framework was Grounded Theory (GT), a method that uses a set of systematized procedures for guiding the collection and analysis of data and developing a theory on a specified phenomenon. ${ }^{16-17}$ 
The study scenario was courses involving the theoretical and practical teaching of pediatric nursing, in the curriculums of the Undergraduate Courses in Nursing of public and private institutions from different regions of Brazil.

A total of 18 lecturers and three nurses participated. These met the following inclusion criteria: to be a professor on the undergraduate course in nursing involved with the process of teaching TP in the theoretical-practical scenario; or to be a nurse, working in the process of teaching TP in the clinical field and/or in assisting in lecturing activities, irrespective of the length of experience in teaching, in both cases.

The number of participants was specified by the process of theoretical sampling, and was configured as the data was analyzed. The concepts that emerged based on the same led to reflections which led to the seeking of other participants for the collection of further data. ${ }^{16-17}$ As a result, four sample groups were made up: professors who worked in the theoretical and practical teaching of TP; those who worked only in the teaching of theory; those who worked only in practical teaching; and those who presented resistance to and/or apparent unawareness of the issue, who were indicated by colleagues who participated in one of the other sample groups.

The data were collected between April 2014 and March 2016. To access the participants, the Snowball sampling method was used, indicated when the population studied is wider. Based on the indication of one or more individuals, it begins with a certain number of people selected, in some way, by the researcher, and who form part of the target-population. ${ }^{18}$

The strategies for accessing the lecturers' experience were: participant observation and semistructured interviews. The first took place in two locales: in the classrooms, and in the environments of academic practice, with interactions being observed between the professor and the students and the content of the TP, in theoretical classes on the topic; in the use of TP by the students, during clinical practice, and also in discussions with the professor. These observations were noted in the field diary, elsewhere, soon after the interactions took place.

The interviews were individual and were recorded, taking between 50 to 100 minutes. These took place in previously agreed locales, and began with the guiding question: "How do you see the teaching of therapeutic play in the Undergraduate Courses in Nursing?". These were transcribed in full and conducted simultaneously with the analysis of the data, which led to further questions, such as: how is the topic addressed in the course that you teach? How do you see the development of the topic of TP in the classroom and in the academic practices?

In order to analyze the data, the steps stipulated by GT were followed. The first stage of the analysis was open codification: the text of each interview was fragmented into small excerpts and examined line by line, allowing the identification of the codes. Based on this, the data were compared in search of similarities and differences, and were grouped in categories. ${ }^{17}$

In the second stage of the analysis, the selective codification, the categories were related to the subcategories, until theoretical saturation was achieved and the central category was identified, permitting the construction of the theoretical model. ${ }^{16-17}$

It is emphasized that data collection began following approval from the Research Ethics Committee. In order to ensure anonymity, the participants were identified with the letter $D$ and the number corresponding to the interview. The observation notes were identified using the letters NO followed by the same identification of the lecturer.

\section{RESULTS}

The analysis of the data revealed categories which were representative of the professor's mobilization for teaching TP in the Undergraduate Courses in Nursing, which is permeated by a constant concern with offering and promoting to the student significant learning, with a view to 
improving the quality of the care for the child. For example: "Seeking to maintain a stimulating climate for learning in the classroom", "Integrating strategies that favor the learning in the environment of academic practice", and "Including the topic in the evaluation process". These integrated one of the phenomenon which make up the experience of the professors teaching TP: "Concerning themselves with offering significant learning to the student". ${ }^{14}$

In this regard, the professor seeks to include various teaching strategies, both theoretical and practical, constantly evaluated and reevaluated, which she believes will have a positive effect on the learning of the topic, as will be described below.

\section{Promoting the dramatization of therapeutic play sessions}

With the intention of making the theoretical content of TP in the classroom closer to the reality of care for the child, and promoting to the student a more concrete knowledge of what a TP session is, the lecturer, as well as offering the theoretical content, proposes dynamics - such as the dramatization of the TP sessions, undertaken by herself or by groups of students.

We included dramatization, [...] we made up two groups, the groups discuss matters between themselves and we finished the class with the dramatization of the TP. (D4)

There were groups that I divided. I went through TP in each group, and did the instruction and the dramatics as well. [...] I gave the theoretical class and afterwards tried to do small workshops with them. (D5)

Reflecting on this strategy, the professor assesses that this activity has an impact on the student's learning, offering greater security at the start of the academic practice, as its undertaking in the classroom allows prior knowledge of what is expected for the development of the TP session to be undertaken by each student.

I think that, besides the theoretical class (TP), the acting out makes a lot of difference because they arrive there [in their practice] less insecure about playing. I thought that it changed quite a lot, and they talk about this during the placement, that the acting out helped [...], they assessed it is very good, and were happy that they had studied this in class before attempting it in the clinical area. (D2)

\section{Recovering childhood and playing}

The lecturer believes that the TP class, on its own, is motivating for the topic of "playing". Encouraged by this belief, during the theoretical class the professor uses the strategy of remembering childhood, sharing events, feelings and sensations experienced by the students, when they played in that period, seeking to bring them closer again with this universe.

The one about playing [the class], I think it encouraged the topic of playing. I think that they [the students] refer to childhood a lot. And thus, this motivates them, and also because we raise their awareness of it a lot [...]. I always try to draw on their own experience, of when they were children, trying to re-remember this with them. (D5)

I begin by asking: what they think about this, if they remember their childhood: "Did you play?" What was it like when you played? [...]. I think this is important, because it will bring back its importance in their lives, and cause them to reflect on the life of the child [the child they will be caring for]. (D3) 
Another strategy used by the professor in the classroom is to propose games with the use of balloons, so as to mobilize in the student pleasurable feelings as they remember playing, relaxing with the games and promoting reflection on this activity in the life of the children who they will be caring for.

The professor proposes a game in which the student writes down their favorite game in childhood on a piece of paper and places it inside a balloon, throwing it up in the air - and this will be best at the end of a song which is accepted with excitement, with conversations taking place in parallel on the childhood games, with laughter and much reminiscing. 'There's a lot of interaction, fun and laughter when they burst the balloons'. 'Professor: can we do this with the children we care for? How will this be for them?'. (NO2, D4)

Seeking to keep the playful atmosphere in the classroom, the lecturer brings along toys used in the TP sessions and costumes, for the undergraduate students to handle, enter into the spirit and accept the invitation to play. The presence of the toys functions as a lure, helping the student to establish fun interactions, with the toy, with classmates and with the professor. The lecturer defines this play activity as something that excites the students, causing them to interact from the beginning to the end of the class.

The class which they interact the most in, from the beginning to the end, is the play class. (D5)

In the theory, when the class was more expositive, we felt the difference - above all, because whenever the toys were brought to the classroom, we placed them there on the table for the students. Most of the time, I had to invite them to step up to the toys and I could already see that they were interested - they took photos, tried on the clothes and played with the dolls. In some way, this was affecting them. (D4)

Most of the students explored the toys, and put on the costumes, such as the glasses and the hats, and played with the hand puppets and with the dolls, having fun and taking photographs of the costumes. After the dramatization of the TP session, all are invited by the professor to explore the toys. (NO2, D5)

\section{Seeking dialogue with the students}

During the class, the lecturer dialogues with the students, sharing experiences related to the use of TP and to the experiments that he or she has undertaken on the topic. They are careful to leave the students at ease to share their ideas in small groups, formed with the task of - together - planning recreational gaming strategies involving TP, in order to include these in their academic practice with the children.

I bring my experience of using the toys, along with examples of my experience with research on TP. (D6)

In this class, there is a point where they got into small groups and discussed what type of thing they could use in the placement. They thought about a proposal for building, for using, a game activity or TP. (D4)

In a meeting on the planning of activities in academic practice with a small number of students, the lecturer - with the objective of dialoguing and planning the care for the hospitalized child, offers the students the possibility to share and consolidate their knowledge on TP.

During the preparatory meeting for practice, the professor asks: How can we listen to our children? How can we know what they are feeling? The students become thoughtful. Student: Ah, we can use play! Lecturer: Very good, And how? What type of play? Student: It could be instructional 
and... Other student: Dramatic? Lecturer: That's right! We can use dramatic and instructional play. Both of them! (NO4, D18).

Another teaching strategy mentioned by the lecturer of the TP class is the use of the Maguerez's Arch method, which he believes promotes dialogue and the more active participation of the student, exposing what the latter knows about the topic and promoting the construction of knowledge in a shared way. This is a methodological path which can be used by the lecturer as a pedagogical practice that allows the student intellectual development and critical thinking, based on prior knowledge actioned in the discussion, stimulating curiosity and maintaining interest. ${ }^{19}$

On the course, we also work with Maguerez's Arch, and do a class on Playing with the Arch. That was a change in itself, because in this theoretical class, the student is participative and we start from her reality to show that the context and construction of the knowledge happened together. (D4)

Another strategy used as a basis for dialogue is to propose prior reading of articles by the students, making time and a reading list available so that the topic will be familiar to them, and they will be able to extend and consolidate their knowledge, generating stimulus for discussion in the classroom and supporting the construction of directed study and the resolving of clinical cases in groups of students.

We work with the articles. There is previous reading to be done so that they are familiarized with the toy, to see the research within play, which I think is extremely important, and to see the importance within a national panorama and within the profession. (D5)

So the article is always handed over [...] And the student has two days or so to read it and a script, to see what the objective is, who the subjects are, how the game was used, the results, and how they perceive the text. (D4)

During the class, we use articles and studies which discuss the impact of hospitalization and the use of play; I hand out articles as complementary material, so that they can do the reading and resolve clinical cases. (D6)

The strategy is assessed by the professor as accepted well by the students. Equally, the professor observes the positive impact on their learning, as she can see that the students who comply as they are asked arrive at the class already much more familiarized with the topic of TP than the students who did not comply with the proposal.

It is accepted very well. It is totally different. If we do this, they are already familiarized with the subject when they turn up - they understand, more or less, what TP is. When the students don't do this, they don't get so much from the class. (D5)

\section{Using audiovisual resources to raise awareness of the learning}

The lecturer adds audiovisual resources to the play strategies, through presenting images of children playing freely, and videos with content raising awareness on care for the child, with the aim of contextualizing and promoting the discussion of the topic.

I use PowerPoint to give the class, and include a lot of photographs of children. (D3)

In the classroom, the professor uses a video of children playing with a pleasant song on in the background. He invites the students to enter into the children's world and you can see they are attentive and smiling with each change of image. At the end, the professor asks: What 
reading did you do? Did you remember your childhood? The students smile, agree, and you quickly find parallel conversations starting up about their experiences of play. (NO2, D2)

\section{Seeing realistic simulation as a possibility for teaching therapeutic play}

On reflecting about new possibilities for teaching the topic, the lecturer sees realistic simulation as a strategy with potential for impacting on raising the student's awareness for TP, when compared to the expositive theoretical class, as it allows the student to visualize, question and validate information prior to experiencing it in practice with a child.

Nowadays, I think that we have new technologies, realistic simulation centers where we can take the students to see where that is done. I think that once you have seen what is being undertaken, the student becomes aware of it more than simply in a class which is 2 or 3 hours long - or more. (D1)

If we could work a little more on the topics of preparing the child for procedures, the issue of play, of dramatization, of the experiences that the child has in hospital, in laboratories where there is realistic simulation, with actors... So that the student can see, reflect, and learn which questions can validate, information, you know? So that we can use this with them later during the practical part. (D18)

\section{Re-presenting therapeutic play to the student at the start of the practical activity}

By extending the teaching of TP to outside the classroom, the professor is concerned with having a second look at the theory on this topic, seeking not only to reinforce the content, but also to plan the care for the child with the student. He also requests the handing-in of the directed study indicated in the theoretical part, discussing it and using it as a basis so that the student is able to establish the relationship between theory and the practical activity of preparation for venipuncture proposed at that point.

Lecturer: Did you say something about playing? Playing how? Picking up a toy and sitting there playing with the child? Student: No, I can apply TP! Lecturer: And which TP is most suited to this? Student: Oh, I can't remember what it's called... Instructional (laughs). Lecturer: The instructional is when I'm going to prepare... Student: I remember! Dramatic. Lecturer: The dramatic - and how do I do that? And, in this way, the student describes the DTP session (Dramatic Therapeutic Play), while the lecturer agrees with gestures, and notes with the students how the DTP technique must be done. (NO4, D18)

When they go to practice, they have to take the filled-out directed study. I say: 'So, we're going to have a discussion about the directed study and we're going to apply TP in practice'. And they hand it over and we have the discussion. (D11)

On beginning the activities in the practice fields, the professor carefully organizes the scenario so that the practice of TP may take place, explaining respect to the mother and to the child, choosing first to undertake a session so that, later, the students will take responsibility for applying it individually or in pairs, under the professor's supervision.

In the practice, I do the demonstration. First, I explain it to the mother, and I apply it with the child, and I repeat it, and I do the TP so that everybody can observe. Then - afterwards - they prepare in pairs: one of the people prepares the saline solution, the material for the person who will do the venipuncture, while the other prepares the child with TP. (D11) 
We divide the children in groups, depending on their age range and on the number of children whose blood is going to be taken. And then - according to age range, we prepare them. Before anything else, I would give them a brief reminder of the theory, one group for them to see how it is, to break the ice, so that they don't feel so intimidated by the professor's presence. (D13)

\section{Broadening the possibilities of the use of therapeutic play}

Seeking to ensure that the content goes beyond the barriers of the classroom, the lecturer is concerned that the student should experience the practice of TP in different environments: hospitals, emergency room, primary care centers and child education centers. In the hospital, the proposals for the use of TP are geared towards the preparation of the child for procedures, such as checking vital signs, venipuncture or dressings, as well as to give the child a voice where they are maltreated, allowing them to express themselves through play.

What you find most is preparation for venipuncture or dressings, because there is always a patient who was burned or hit by a car. As a result, there are always dressings to be put on. (D16)

One student said, for example, that he was going to check the vital signs and went ahead and showed the dolly to the child - and said that he was going to check the dolly's vital signs, and asked if she wanted to help. (D4)

Two students have the TP box. I go up to them and ask them: what you going to do? Student: We are taking responsibility for $D$., 2 years and 7 months, and we are going to do TP. He has been maltreated and we decided to do TP because he is reluctant and doesn't let anybody touch his body, not even to take a bath. (NO, D18)

As well as preparation for painful procedures, such as venipuncture, the lecturer also emphasizes to the student the need to use TP with children in situations of trauma or urgency, even when it is not possible to prepare the child prior to the operation.

The applied technique [TP], as teaching, is done basically for preparation for venipuncture and with children with orthopaedic trauma, who have dressings and normally were not able to receive any preparation prior to surgery. As they come from a situation of trauma or urgency, in this case, it is done later, when one places the dressings on the dolly, to show how it is, and tell a story and ask the child to play with the material. (D17)

As a result, in the scenario of academic practice in the hospital, the lecturer takes advantage of the opportunities for the student to use TP, in the light of the child's needs, planning actions with its use, as with any other technique undertaken and with the same importance.

For example, he [the student] prepares the child for venipuncture. So - he plans, and carries out the technique - normally this lasts for half an hour, as he demonstrates, and then the child handles the materials, plays, chats and tells a story. He enters his routine, this isn't - like exceptional - it's part of the care like any other thing. We treat this technique (TP) like any other, with the same importance as the others. (D17)

In primary health care, the opportunities for teaching and using TP take place during the nursing consultation, physical examinations, preparation for using an inhaler, taking bloods and in the vaccination room, which, in the assessment of the lecturer, is something that the students really like doing.

In primary care, they use it for consultations, for preparing to use an inhaler, or for physical examinations. There are some days of the week that they're there and there are people taking bloods, and I encourage them to do the preparation. (D11) 
Play is used almost routinely with children. In the nursing consultation, we use it all the time, and our experience of it is really good, and the students, even when they don't pass the first time they prepare the child for the taking of bloods, have this experience in the nursing consultation. And they like it a lot. (D13)

In the child education center, on the other hand, the professor supervises the students, giving them the opportunity to interact with the children who present difficulties adapting to school and helping them to eat better through applying Dramatic TP.

Playing, for the child at crèche, and applying TP takes place, for example, when they think that there is a child who is not adapting. We do TP with her. Is a child not eating anything? We use DTP with the child. (D3)

\section{Providing the material for the practice of therapeutic play.}

In order for the student to be able to experience the practice of TP, the professor builds a TP kit for the course and shares her own material with the students and with the other lecturers and, what is more, recommends the students to include a ragdoll as an item to be carried in their bag.

What we professors discussed among ourselves is that we try to build a collection of material that stays here in the group, the course. In the beginning, one group uses it - and then, a different one does. (D4)

I have the course's kit, which I leave there in the classroom. And the students come with toys of theirs which have already been incorporated into the material we carry with us. On the first day of class, the professor provides the basic guidance for the course; and passes on a list of the material to be carried around. 'Thermometer and... a ragdoll'. (D11)

\section{Including the topic in the process of the student's assessment}

Although throughout the teaching process one finds the sharing of ideas between students and professors, both in the classroom and in the practical activity environments, the lecturer reflects on the need for assessing the learning, also through formal strategies, such as a written test and the handing in of reports. In addition to this, the professor requires at least one TP session to be undertaken during the practice, in any one of its fields, which will influence the student's final grade.

I believe that they have to have tests. TP, in my opinion, must be required not only in practice, but also in theory. (D5)

We have a test. In every test, we include a question about TP. This is a content which is required of the student. (D11)

They do a report on the activity which was done on the day and they need to integrate the practice undertaken with the theory. P: Does this report get graded? D: Yes it does, a small mark compared with the total mark for the course. P: And is there another way to assess this content? D: The content, yes, it is part of the course, of the curriculum - and, therefore, it is also found in the written test. (D13)

As I go to the placements, I establish that they will have to do at least one TP session with the children in one of the two fields. This is required of them, and they receive a grade relating to this activity. (D1) 


\section{DISCUSSION}

The concepts described in the categories presented made it possible to understand that the lecturer's concern and responsibility in the construction of knowledge on TP permeate the entire teaching-learning process, mobilizing the professor to seek new ways of innovating the teaching and motivating the student's interest in the topic. As a result, she comes to develop participative methodologies and adopts different pedagogical methodologies with the aim of promoting a listening space for the student.

These findings agree with what is being applauded in the literature, regarding the need to incorporate strategies which activate the students into the teaching process, involving them in the process of thinking, elaborating new meanings, learning and acting. ${ }^{20-21}$

Meta-analysis undertaken with the aim of assessing the effectiveness of teaching strategies for developing critical thinking in undergraduate nursing students has revealed that problem-based learning (PBL) is one of the effective methods in increasing scores for critical thinking, confirming the hypothesis that active teaching strategies are more effective..$^{22}$

The use of these methodologies has the potential to develop autonomy and critical thinking in the student, and to wake her up to the fact that learning becomes significant to the student, emphasizing: case studies, videos, dramatizations, group discussions, integrated panels, Role-playing Game (RPG), teamwork, online programs, pedagogical workshops, participation and extension projects and the use of the laboratory. ${ }^{22-23}$ Many of them were used in the teaching of TP by the professors in this study, which, according to them, allowed the students to clarify doubts and gave them greater confidence for experiencing it in their academic practice.

The professors also showed their wish to incorporate realistic simulation as a teaching methodology, which promotes the significant learning of TP. The literature emphasizes simulated practice as a positive strategy, as - when it is used prior to the student being placed in clinical practice - it ensures the development of the skills necessary to minimize errors when the students are in a real context. ${ }^{24}$

The encouragement for its use is related to the fact that it facilitates the communication between professor and student, that it offers a more secure learning environment, and helps to develop clinical expertise and confidence for decision-making, with consequent greater safety for the patient who will be cared for in the clinical environments. ${ }^{25}$

Nevertheless, as the literature emphasizes, the student must be predisposed to learning and the professor has the role of selecting the potentially significant material - that is, what makes sense to her, in order to promote links with prior knowledge..$^{23}$

For this, students who participated in a study on the teaching and practice of TP in the undergraduate nursing course suggested that the professor should address, in the theoretical teaching of the topic, reports on his or her professional experiences with the use of the intervention, that the professor should offer case studies and discussion of articles, and should use videos and dramatizations of TP sessions so as to encourage and stimulate the learning. In academic practice, the students recommended that a specific time period of sufficient length should be made available for them to experience the use of TP, with support and encouragement from the professor. ${ }^{26}$

In this study, the professors who were moved by the belief that the topic of playing, per se is motivating, as well as providing in the classroom the toys that make up the material stipulated in the TP sessions for the students to handle, undertook play dynamics, with the intention of recording events, sentiments and feelings experienced in childhood while the students were interacting with playing. Concomitantly, they used videos to raise awareness of the topic, and songs related to play.

This movement undertaken by the professor links with studies that reveal the need for the lecturer to provide an educational atmosphere that favors meaning, so that the student may feel 
respected in her differences and her values and thus be able to be adventurous and open up to the experience brought by the professor. ${ }^{27}$

We agree that in the teaching of nursing, teaching situations based in real situations, such as those described above, enrich the teaching-learning process, because they viabilize a situation which is closer to reality and clarify how the student should behave with the small patient, providing an appropriate time for the lecturer to intervene in the construction of the knowledge. ${ }^{23}$

This study also revealed that the lecturer seeks to promote dialogue with the students, recovering theoretical concepts, including analogies and examples that she has experienced in her routine with TP, allowing the student to share her doubts and anxieties and reflect on the relationship between the theoretical bases and the academic practice. In this regard, the use of Maguerez's Arch ${ }^{19}$ allowed dialogue and the exchanging of knowledge and experiences related to the topic.

Research has evidenced that although the students initially resist the proposal of Problematization through the use of Maguerez's Arch in the teaching of TP, this methodology was shown to be significant in the teaching, as it allowed interlinking between theory and practice, and the exercising of the collective construction of knowledge and encouragement to the students' creativity and critical thinking. ${ }^{28}$

It should be emphasized that when the professor proposes discussions on TP in small groups in the classroom, as undertaken by the lecturers studied here, this contributes not only to consolidating concepts on the topic, but also to acquiring communication skills, ${ }^{29}$ although - from the student's perspective - this collaborative learning strategy is questioned, as these do not perceive it as favoring the gaining of knowledge, causing them to lose time which could be spent studying. ${ }^{30}$

The lecturer's concern with extending the possibilities for the use of TP outside the classroom is shown to be of fundamental importance, as the student recognizes that, upon interacting with the child and TP during clinical practice, she is surprised and impressed by the benefits that emerge from this interaction and the difference that it promotes in the care, favoring not only the child and the family, but the student as well - who feels gratified. ${ }^{26}$

Depending on how the student is during this practice, he may come to understand TP as a communication strategy that benefits the child, as it minimizes the stress resulting from a difficult situation, as well as demystifying the figure of the nurse as somebody who only causes pain. He also emphasizes that it is through the practical activity of TP that the student comes to give meaning to the theory addressed on the topic in the classroom ${ }^{26}$

In the light of the above, we believe that it will be possible to keep the classroom as a teachinglearning atmosphere if the educational project is innovative and considers active methodologies. Although few studies mentioned the lecturers' concern with using these, it is fundamental for the learning that they should be prepared to advise their students, causing these to feel that they are protagonists of a learning that is rich and stimulating. ${ }^{23}$

This article limited itself to describing the professor's search and perception regarding the use of teaching strategies, so as to promote significant learning of TP, with a view to improving the quality in the care provided to the child. As a result, other studies must be undertaken, related both to the experience of using the strategies mentioned in this article, and to others, such as referring to the effects of its use in the student's learning, with the aim of promoting the extending of the stateof-the-art on the teaching of TP.

\section{CONCLUSION}

The study made it possible to investigate didactic strategies used by the professor in the teaching of TP, that the professor considers effective for motivating the student and giving her significant learning, both in the theoretical field and in clinical practice. In this way, the hope is to help the lecturers in the task of awakening and introducing the student to the universe of TP, promoting its 
learning and the systematic incorporation of this important technology of care in academic life and in the future as a nurse.

It is known that there is much space for improvement not only in how the content of TP is worked with, but also in how to evaluate whether the learning was indeed significant, and the effect that this will have on the student's life, as a professional who is responsible for promoting the inclusion of TP in the care for the child, preserving and protecting the child's right to receive the care which she deserves.

\section{REFERENCES}

1. Fernandes JD, Rebouças LC. A decade of National Curriculum Guidelines for Graduation in Nursing: advances and challenges. Rev Bras Enferm [Internet]. 2013 [cited 2017 Mar 02];66(esp):95-101. Available from: http://dx.doi.org/10.1590/S0034-71672013000700013

2. Fernandes JD, Silva RMO, Teixeira GA, Florencio RMS, Silva LS, Rebouças LCC. Aderência de Cursos de Graduação em Enfermagem às Diretrizes Curriculares Nacionais na perspectiva do Sistema Único de Saúde. Esc Anna Nery [Internet]. 2013 [cited 2017 Mar 17];17(1):82-89. Available from: https://doi.org/10.1590/S1414-81452013000100012

3. Ministério da Educação (Brasil). Conselho Nacional de Educação. Câmara de Educação Superior. Resolução CNE/CES 3/2001: Institui as diretrizes curriculares nacionais do curso de Graduação em Enfermagem. Diário Oficial da República Federativa da União. Brasília [Internet], 09 nov. 2001, Seção 1, p 37 [cited 2017 Mar 25]. Available from: http://portal.mec.gov.br/cne/arquivos/ pdf/CES03.pdf

4. Coelho LP, Rodrigues BMRD. O cuidar da criança na perspectiva da bioética. Rev Enferm UERJ [Internet]. 2009 [cited 2017 Mar 08];17(2):188-93. Available from: http://www.facenf.uerj.br/v17n2/ v17n2a08.pdf

5. Sociedade Brasileira de Enfermeiros Pediatras. Carta de Gramado [Internet]. 2013 [cited 2017 Mar 25]. Available from: http://sobep.org.br/v-congresso/

6. International Play Association. Declaration on the importance of play [Internet]. 2014. [cited 2017 Feb 20] Available from: http://www.IPAworld.org

7. Ribeiro CA, Borba RIH, Maia EBS. O preparo da criança e da família para procedimentos terapêuticos. In: Associação Brasileira de Enfermagem, org. PROENF Programa de Atualização em Enfermagem: Saúde da Criança e do Adolescente: Ciclo 8. Porto Alegre, RS: Artmed/ Panamericana;2013:9-50.

8. Vessey JA, Mahon MM. Therapeutic play and the hospitalized child. J Pediatr Nurs. 1990;5(5):328333.

9. Oliveira CS, Maia EBS, Borba, RIH, Ribeiro CA. Brinquedo Terapêutico na assistência à criança: percepção de enfermeiros das unidades pediátricas de um hospital universitário. Rev Soc Bras Enferm Ped [Internet]. 2015 [cited 2017 Mar 15];15(1):21-30. Available from: https://sobep.org. br/revista/images/stories/pdf-revista/vol15-n1/vol_15_n_2-artigo-de-pesquisa-3.pdf

10. Francischinelli AGB, Almeida FA, Fernandes DMSO. Routine use of therapeutic play in the care of hospitalized children: nurses' perceptions. Acta Paul Enferm [Internet]. 2012 [cited $2017 \mathrm{Apr}$ 02];25(1):18-23. Available from: http://dx.doi.org/10.1590/S0103-21002012000100004

11. Baldan JM, Santos CP, Matos APK, Wernet M. Adoption of play/toys in the assistence practice to hospitalized children: nurse's trajectory. Cienc Cuid Saude [Internet]. 2014 [cited $2017 \mathrm{Apr}$ 05];13(2):228-35. Available from: http://www.periodicos.uem.br/ojs/index.php/CiencCuidSaude/ article/viewFile/15500/pdf_197

12. Cunha MLR, Costa JB, Almeida FA, Maia MM. Crenças do enfermeiro na promoção da autonomia do escolar com câncer frente aos procedimentos de enfermagem. Investigação Qualitativa em Saúde. Atas CIAIQ. 2016;2:1214-1223. 
13. Manav G, Ocakci AF. Play Model for evaluation of self-concept of children with cancer. Iran J Nurs Midwifery Res [Internet]. 2016 [cited 2017 Apr 05];21(2):124-130. Available from: https://doi. org/10.4103/1735-9066.178227

14. Maia EBS. Empenhando-se em promover um ensino significativo do Brinquedo Terapêutico, almejando a qualidade do cuidado à criança: vivência do docente de graduação em enfermagem [tese]. [São Paulo, SP]: Universidade Federal de São Paulo, Programa de Pós-Graduação em Enfermagem;2016. 290 p.

15. Charon JM. Symbolic interactionism: as introduction, an interpretation, an integration. 10th ed. Englewood Cliffs: Prentice-Hall;2010.

16. Corbin J, Strauss A. Basics of qualitative reseach. techniques and procedures for developing Grounded Theory. 4th ed. Thousand Oaks, US: SAGE Publications;2015.

17. Charmaz K. Constructing Grounded Theory. 2nd ed. Thousand Oaks, US: SAGE Publications;2014.

18. Vinuto J. A amostragem em bola de neve na pesquisa qualitativa: um debate em aberto. Temáticas. 2014;22(44):203-220.

19. Prado LM, Velho MB, Espindola DS, Sobrinho SH, Backes VMS. Arco de Charles Maguerez: refletindo estratégias de metodologia ativa na formação de profissionais de saúde. Esc Anna Nery [Internet]. 2012;16(1):172-177. Available from: https://doi.org/10.1590/S1414-81452012000100023

20. Barbosa EF, Moura DG. Metodologias ativas de aprendizagem na educação profissional e tecnológica. Bol Tec Senac. 2013;39(2):48-67.

21. Soares AN, Gazzinelli MF, Souza V, Araujo LHL. The Role Playing Game (RPG) as a pedagogical strategy in the training of the nurse: an experience report on the creation of a game. Texto Contexto Enferm [Internet]. 2015 [cited 2017 Apr 05];24(2):600-8. Available from: http://dx.doi. org/10.1590/0104-07072015001072014

22. Oliveira LB, Diaz LJR, Carbogim FC, Rodrigues ARB, Puschel VAA. Effectiveness of teaching strategies on the development of critical thinking in undergraduate nursing students: a metaanalysis. Rev Esc Enferm USP [Internet]. 2016 [cited 2017 Apr 05];50(2):355-364. Available from: https://doi.org/10.1590/S0080-623420160000200023

23. Sousa ATO, Formiga NS, Oliveira SHS, Costa MML, Soares MJGO. Using the theory of meaningful learning in nursing education. Rev Bras Enferm [Internet]. 2015 [cited 2017 Apr 05];68(4):713-22. Available from: http://dx.doi.org/10.1590/0034-7167.2015680420i

24. Martins JCM, Mazzo A, Baptista RCN, Coutinho VRD, Godoy S, Mendes IAC, Trevizan MA. The simulated clinical experience in nursing education: a historical review. Acta Paul Enferm [Internet]. 2012 [cited 2017 Apr 05];25(4):619-25. Available from: http://dx.doi.org/10.1590/S010321002012000400022

25. Quilici AP, Bicudo AM, Gianotto-Oliveira R, Timerman S, Gutierrez F, Abrão KC. Faculty perceptions of simulation programs in healthcare education. Inter J Med Educ [Internet]. 2015 [cited $2017 \mathrm{Apr}$ 05];6:166-171. Available from: https://doi.org/10.5116/ijme.5641.0dc7

26. Barreto LMSC, Maia EBS, Depianti JRB, Melo LL, Ohara CVS, Ribeiro CA. Giving meaning to the teaching of Therapeutic Play: the experience of nursing students. Esc Anna Nery [Internet]. 2017 [cited 2017 Sep 05];21(2):e20170038. Available from: https://doi.org/10.5935/1414-8145.20170038

27. Souza MVL, Lopes ES, Silva LL. Aprendizagem significativa na relação professor-aluno. Rev Cienc. Humanas. 2013;13(2):407-420. 
28. Fujita JALM, Carmona EV, Shimo AKK, Mecena EH. Uso da metodologia da problematização com o Arco de Maguerez no ensino sobre o brinquedo terapêutico. Rev Port Educ [Internet]. 2016 [cited 2016 Oct 23];29(1):229-58. Available from: http://dx.doi.org/10.21814/rpe.5966

29. Oliveira KRE, Braga EM. The development of communication skills and the teacher's performance in the nursing student's perspective. Rev Esc Enferm USP [Internet]. 2016 [cited $2017 \mathrm{Apr}$ 05];50(spe.):32-38. Available from: https://doi.org/10.1590/S0080-623420160000300005

30. Rodríguez-Borrego MA, Nitschke RG, Prado ML, Martini JG, Guerra-Martín MD, González-Galán C. Theoretical assumptions of Maffesoli's sensitivity and Problem-Based Learning in Nursing Education. Rev Latino-Am Enfermagem [Internet]. 2014 [cited 2017 Apr 05];22(3):504-510. Available from: https://doi.org/10.1590/0104-1169.3065.2444 


\section{NOTES}

ORIGIN OF THE ARTICLE

Article extracted from the dissertation - Striving to promote significant teaching of therapeutic play, aiming for quality in care for the child: the experience of the lecturer in Undergraduate Courses in Nursing, presented to the Programa de Pós Graduação em Enfermagem, Universidade Federal de São Paulo, in 2016.

\section{CONTRIBUTION OF AUTHORITY}

Study design: Mendes Maia EBS, Ohara CVS, Ribeiro CA.

Data analysis and interpretation: Maia EBS, Ohara CVS, Ribeiro CA.

Writing and / or critical review of content: Maia EBS, Ohara CVS, Ribeiro CA.

Review and final approval of the final version: Maia EBS, Ohara CVS, Ribeiro CA.

\section{FUNDING INFORMATION}

Not applicable.

\section{ETHICS COMMITTEE IN RESEARCH}

Approved by the Ethics Committee in Research with Human Beings of the Universidade Federal de São Paulo, 394.373/2013and Certificate of Presentation for Ethical Appreciation (CAAE): 20881713.7.0000.5505

\section{CONFLICT OF INTEREST}

No any conflict of interest.

\section{HISTORICAL}

Received: May 05, 2017.

Approved: January 29, 2018.

\section{CORRESPONDENCE AUTHOR}

Edmara Bazoni Soares Maia

edmara@ronaldomaia.com.br 